\title{
Response of okra (Abelmoschus esculentus (L.) Moench) and soil properties to different mulch materials in different cropping seasons
}

\author{
A.O. Adekiya ${ }^{a}$, T.M. Agbede ${ }^{\mathrm{b}, *}$, C.M. Aboyeji ${ }^{\mathrm{a}}$, O. Dunsin ${ }^{\mathrm{a}}$ \\ a Department of Crop and Soil Sciences, Landmark University, P. M. B. 1001, Omu-Aran, Kwara State, Nigeria \\ b Department of Agricultural Technology, Rufus Giwa Polytechnic, P.M.B. 1019, Owo, Ondo State, Nigeria
}

\section{A R T I C L E I N F O}

\section{Article history:}

Received 9 September 2016

Received in revised form 28 January 2017

Accepted 31 January 2017

\section{Keywords:}

Okra

Soil bulk density

Temperature

Soil chemical properties

Leaf nutrient composition

Grass

Legume

\begin{abstract}
A B S T R A C T
The type of materials used as mulch and season of application may determine its impact on soil physical and chemical properties and crop yield. Hence, field experiments were carried out during 2015 (dry) and 2016 (wet) cropping seasons to determine the effect of various mulch materials on soil properties, leaf nutrient composition, yield and growth of okra (Abelmoschus esculentus (L.) Moench). The experiment consisted of four mulch materials (a) Pueraria phaseoloides, (b) Mucuna pruriens, (c) Pennisetum purpureum), (d) Panicum maximum and a control (no mulch application). The five treatments were arranged in a randomized complete block design with four replications. Application of mulch reduced bulk density, soil temperature and increased porosity, soil moisture content, $\mathrm{pH}, \mathrm{OM}$, soil and leaf $\mathrm{N}, \mathrm{P}, \mathrm{K}, \mathrm{Ca}, \mathrm{Mg}$, pod yield and growth of okra compared with the control. Legume mulch materials (LMM) (Pueraria and Mucuna) produced higher values of OM, N, P, K, Ca and $\mathrm{Mg}$ compared with grass mulch materials (GMM) (Pennisetum and Panicum) in both seasons. GMM significantly $(\mathrm{p} \leq 0.05)$ reduced bulk density and soil temperature and increased porosity and moisture content compared with the LMM in 2015. The correlation coefficient showed that the yield of okra in 2015 was dependent on soil physical properties while the yield in 2016 was dependent on soil chemical properties. GMM in 2015 produced $49 \%$ and $158 \%$ higher pod yield compared with LMM and the control, respectively. LMM increased the pod yield of okra in 2016 by $56 \%$ and $122 \%$ compared with GMM and the control, respectively. Therefore the use of grass materials as mulch in the dry season and the use of legume mulches during the wet season maximized yields.
\end{abstract}

(c) 2017 Elsevier B.V. All rights reserved.

\section{Introduction}

Okra (Abelmoschus esculentus (L.) Moench) is a vegetable crop and a member of the family Malvaceae. Okra probably originated from East Africa and today is widely distributed in the tropics, subtropics and warmer parts of the temperate region (Echo, 2003). Okra plays an important role in human diet by supplying carbohydrates, proteins, fats, minerals and vitamins that are usually deficient in the stable food (main food source such as rice) (Abd El-Kader et al., 2010). The essential and non- essential amino acids that okra contains are comparable to that of soybean (Farinde et al., 2007). In Nigeria, okra is mainly used in making soup and is eaten along with pudding food (food made from flour and does not involve chewing but instant swallow and is traditionally eaten with fingers).

Despite the numerous benefits and nutritional value of okra, its optimum yields ( $2-3 \mathrm{tha}^{-1}$ ) and quality have not been attained in

\footnotetext{
* Corresponding author.

E-mail address: agbedetaiwomichael@yahoo.com (T.M. Agbede).
}

the tropical countries partly because of a continued declined in soil fertility. One of the ways to increase yield of okra in order to meet its global demand is the application of mulch materials at different cropping seasons. In Nigeria, there are two distinct seasons for okra, the peak and the lean seasons. During the peak season (wet season), okra is produced in large quantities, much more than what the populace can consume. During the lean season, okra fruits are produced in low quantities, and does not meet demand (Bamire and Oke, 2004). The lean season of okra production falls within the second cropping season and the dry season, hence soil water conservation and soil temperature moderation is important. Okra plants require warm temperatures and is unable to tolerate low and high temperature for long time. The optimum soil temperatures are in the range of $21-30^{\circ} \mathrm{C}$, with minimum soil temperatures of $18^{\circ} \mathrm{C}$ and maximum of $35^{\circ} \mathrm{C}$ (Abd El-Kader et al., 2010). Okra is a high water use despite having notable drought tolerant (Ghannad et al., 2014). The plant forms a deeply penetrating tap root with dense shallow feeder roots reaching out in all directions in the upper $0.45 \mathrm{~m}$ of soil. For high yield, adequate water supply and relatively moist soils are required during the total growing period (Abd El-Kader et al., 2010). These authors reported that application of $1798.2 \mathrm{~m}^{3}$ /acre of water 
Table 1

Meteorological data of the study area.

\begin{tabular}{|c|c|c|c|c|c|c|c|}
\hline & \multicolumn{2}{|c|}{ Aug. 2015} & Sep. 2015 & Oct. 2015 & \multicolumn{2}{|c|}{ Nov. 2015} & \multirow{2}{*}{$\begin{array}{l}\text { Dec. } 2015 \\
0\end{array}$} \\
\hline Rainfall (mm) & 62 & & 293.8 & 119.6 & & & \\
\hline Relative humidity (\%) & 91 & & 92.2 & 89.7 & & & 39.2 \\
\hline \multirow[t]{2}{*}{ Mean temperature $\left({ }^{\circ} \mathrm{C}\right)$} & 22 & & 22.8 & 25.7 & & & 27.9 \\
\hline & Jan. 2016 & Feb. 2016 & Mar. 2016 & Apr. 2016 & May 2016 & Jun. 2016 & Jul. 2016 \\
\hline Rainfall (mm) & 0 & 5.1 & 99.8 & 148.7 & 186.4 & 183.4 & 245.2 \\
\hline Relative humidity (\%) & 35.7 & 45.6 & 76.5 & 81.4 & 88.1 & 82.4 & 93.5 \\
\hline Mean temperature $\left({ }^{\circ} \mathrm{C}\right)$ & 27.6 & 27.1 & 25.1 & 24.4 & 24.2 & 23.1 & 24.6 \\
\hline
\end{tabular}

Source: Meteorological unit, Landmark University, Omu-Aran, Kwara State, Nigeria.

Table 2

Soil physical and chemical analysis of the experimental site before experimentation.

\begin{tabular}{ll}
\hline Parameter & Value \\
\hline Sand (\%) & 75 \\
Silt (\%) & 14 \\
Clay (\%) & 11 \\
Textural class & Sandy loam \\
Bulk density $\left(\mathrm{Mg} \mathrm{m}^{-3}\right)$ & 1.49 \\
Total porosity $(\%)$ & 43.5 \\
pH (water) & 5.58 \\
Organic matter $(\%)$ & 2.85 \\
Total N (\%) & 0.16 \\
Available P $\left(\mathrm{mg} \mathrm{kg}^{-1}\right)$ & 10.6 \\
Exchangeable $\mathrm{K}\left(\mathrm{cmol} \mathrm{kg}^{-1}\right)$ & 0.14 \\
Exchangeable Ca $\left(\mathrm{cmol} \mathrm{kg}^{-1}\right)$ & 1.8 \\
Exchangeable ${\mathrm{Mg}\left(\mathrm{cmol} \mathrm{kg}^{-1}\right)}$ & 0.36 \\
\hline
\end{tabular}

to okra plant through drip irrigation was found to be sufficient for the plant. An efficient use of limited water resources during the dry/lean season is important. There is, therefore, a need to study the effect of soil management practices on soil water, temperature, soil density, nutrient supply and okra yield. These practices include mulching.

Mulching is reported to ameliorate soil moisture deficient and extremely high soil temperature regimes, mitigate low temperatures and improves soil fertility and yield of crops (Agele et al., 2000; Olasantan, 1988; Adekiya et al., 2015) and eliminate compaction of ridges and mounds (Aina, 1979). Mulching has also been shown to improve water infiltration, reduce evaporation and runoff, control weeds and improve soil structure (Olasantan, 1988). Mulching is practicable in derived-savannah zone of Nigeria due to high rainfall of the wet season and resulting heavy vegetation growth. It has been reported (Hochmuth et al., 2015) that tomatoes, peppers, egg plants, strawberries and melons are produced under mulches in southern Florida. In India, okra production increased significantly under straw mulch following saw dust mulch over control. The application of straw mulch increased tomato and okra yield over the control (Batra et al., 1985; Gupta and Gupta, 1987). However, research information is scarce on response of okra to mulch materials in Nigeria.

Elephant grass (Pennisetum purpureum) and Guinea grass (Panicum maximum) are of the family Poaceae and are common grasses in every ecological zone in Nigeria. The effectiveness of using elephant grass (Pennisetum purpureum) as mulching material was evaluated in the laboratory using a rainfall simulation set at rainfall intensities typical of the tropics (Adekalu et al., 2006). The results of the study showed that mulching the soil with elephant grass residue may benefit cropping (second cropping) by increasing stored soil water for use during dry weather and help to reduce erosion on sloping land. In Peru (Wade and Sanchez, 1983), mulching with guinea grass decreased top soil temperature by $5^{\circ} \mathrm{C}$ prior to the establishment of a crop canopy, conserved soil moisture in the top $5 \mathrm{~cm}$ during dry weather, prevented surface crusting and decreased weed emergence. Ewulo et al. (2011) also reported that when elephant grass and guinea grass were applied to yam (Dioscorea rotundata), the mulch materials increased vine length, number of branches and leaves, tuber weight, leaf N, P, K, Ca and Mg significantly $(\mathrm{p} \leq 0.05)$ compared with the control. Tropical kudzu (Pueraria phaseoloides) has been found to protect the soil from erosion and loss of plant nutrients through leaching and runoff (Tian et al., 2001). Velvetbean (Mucuna pruriens) has been found to modify the structure, composition, diversity and interaction of soil biota that can promote soil structure and nutrient availability (Ortiz-Ceballos and Fragoso, 2004).

The type of materials used as mulch and the time (cropping season) they are applied may determine its impact on soil physical and chemical properties and crop yield. This is due to the biochemical qualities of the plant materials. Soil fertility enhancement due to mulching can be attributed to the promotion of microbial activity and consequent enhancement of decomposition of organic material (Agele et al., 2010). Mulches can bring a lot of $\mathrm{N}$ and $\mathrm{P}$ to the soil and therefore reduce the need for other nutrient inputs. However, there is scanty information on the use of different mulch materials at different cropping seasons on soil properties, growth and yield of okra. There is a need to ascertain the extent to which different weed species could be used as mulch at different cropping seasons for soil improvement and okra performance. Therefore, the objective of the current study was to compare the effect of elephant grass (Pennisetum purpureum), guinea grass (Panicum maximum), tropical kudzu (Pueraria phaseoloides) and Velvetbean (Mucuna pruriens) applied as mulch at different cropping seasons on soil properties, leaf nutrient concentrations, growth and okra yield. It was hypothesized that soil properties (at different cropping seasons) and okra yield will react differently to different mulch materials. Experiments were conducted to evaluate these working hypothesis; which seasons or mulch treatments will have greater effect?

\section{Materials and methods}

\subsection{Site description and treatments}

Field experiments were carried out at the Teaching and Research Farm, Landmark University, Omu-Aran, Kwara State, Nigeria during 2015 (dry) and 2016 (wet) cropping seasons. Landmark University lies between lat $8^{0} 9^{\prime} \mathrm{N}$ and long $5^{0} 61^{\prime} \mathrm{E}$ and is located in the derived savanna ecological zone of Nigeria. The rainfall pattern was bimodal with peaks in June and October (Table 1). The total annual rainfall in the area was about $1227 \mathrm{~mm}$ in 2015 with mean air temperature of $26.2^{\circ} \mathrm{C}$ and mean relative humidity of $75.9 \%$. In 2016, the total annual rainfall in the area was about $1240 \mathrm{~mm}$ with mean air temperature of $27.3^{\circ} \mathrm{C}$ and mean relative humidity of $78.5 \%$. The soil at the site of the experiment is an Alfisol classified as Oxic Haplustalf or Luvisol (Adekiya et al., 2015). The experimental area was cropped with maize for two years, left fallow for two years, then mechanically cleared by ploughing and harrowing. 
Table 3

Chemical composition of mulch materials used for the experiment.

\begin{tabular}{|c|c|c|c|c|c|c|c|}
\hline Mulch material & $\mathrm{C}(\%)$ & $\mathrm{N}(\%)$ & $\mathrm{C}: \mathrm{N}$ & $\mathrm{P}(\%)$ & $\mathrm{K}(\%)$ & $\mathrm{Ca}(\%)$ & $\operatorname{Mg}(\%)$ \\
\hline Pueraria phaseoloides & $44.5 \mathrm{a}$ & $3.05 b$ & $14.6 \mathrm{~b}$ & $0.18 b c$ & $2.25 a$ & $0.39 b$ & $0.27 d$ \\
\hline Mucuna pruriens & $43.9 a$ & $3.40 \mathrm{a}$ & $12.9 \mathrm{a}$ & $0.27 a$ & $1.61 b$ & $0.31 \mathrm{c}$ & $0.35 c$ \\
\hline Pennisetum purpureum & $38.2 b$ & $1.62 \mathrm{c}$ & $23.6 c$ & $0.16 \mathrm{~d}$ & $1.45 \mathrm{c}$ & $0.85 a$ & $0.42 b$ \\
\hline Paniucum maximum & $39.4 b$ & $1.70 \mathrm{c}$ & $23.2 \mathrm{c}$ & $0.19 b$ & $1.28 \mathrm{~d}$ & $0.41 b$ & $0.58 \mathrm{a}$ \\
\hline
\end{tabular}

Values followed by similar letters under the same column are not significantly different at $\mathrm{p} \leq 0.05$ according to Duncan's multiple range test

Table 4

Effect of various mulch materials on soil physical properties in 2015 (dry) season and 2016 (wet) season okra production.

\begin{tabular}{|c|c|c|c|c|c|}
\hline Year/season & Mulch material & Bulk density $\left(\mathrm{Mg} \mathrm{m}^{-3}\right)$ & Total porosity (\%) & Moisture content (\%) & Temperature $\left({ }^{\circ} \mathrm{C}\right)$ \\
\hline \multirow[t]{5}{*}{2015 (Dry) } & Control & $1.57 \mathrm{a}$ & $40.75 c$ & $9.04 \mathrm{c}$ & 41.10a \\
\hline & Pueraria phaseoloides & $1.42 \mathrm{~b}$ & $46.40 \mathrm{~b}$ & $11.60 \mathrm{~b}$ & $35.10 \mathrm{~b}$ \\
\hline & Mucuna pruriens & $1.47 \mathrm{~b}$ & $44.50 \mathrm{~b}$ & $11.12 \mathrm{~b}$ & $36.20 \mathrm{~b}$ \\
\hline & Pennisetum purpureum & $1.31 \mathrm{c}$ & $50.50 a$ & $14.10 \mathrm{a}$ & $31.20 \mathrm{c}$ \\
\hline & Paniucum maximum & $1.32 \mathrm{c}$ & $50.20 \mathrm{a}$ & $14.90 a$ & $30.80 c$ \\
\hline \multirow[t]{5}{*}{2016 (Wet) } & Control & $1.60 \mathrm{a}$ & $39.62 b$ & $11.20 c$ & $36.6 a$ \\
\hline & Pueraria phaseoloides & $1.37 \mathrm{~b}$ & $48.30 \mathrm{a}$ & $14.60 \mathrm{ab}$ & $29.1 b$ \\
\hline & Mucuna pruriens & $1.39 b$ & $47.50 \mathrm{a}$ & 14.80ab & $29.6 b$ \\
\hline & Pennisetum purpureum & $1.32 \mathrm{~b}$ & $50.18 a$ & $15.30 a$ & $28.1 b$ \\
\hline & Paniucum maximum & $1.32 \mathrm{~b}$ & $50.18 a$ & $15.80 a$ & $28.3 b$ \\
\hline $\operatorname{Year}(\mathrm{Y})$ & * & $*$ & $*$ & * & * \\
\hline Mulch material (M) & $*$ & $*$ & $*$ & $*$ & * \\
\hline $\mathrm{Y} \times \mathrm{M}$ & $*$ & $*$ & * & $*$ & $*$ \\
\hline
\end{tabular}

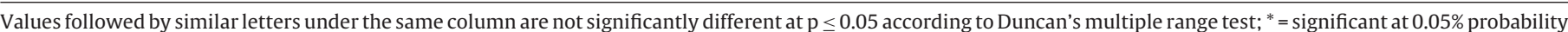
level.

The experiment consisted of four types of mulch materials $\{(\mathrm{a})$ Tropical kudzu: Pueraria phaseoloides (Roxb) Benth,(b) Velvetbean: Mucuna pruriens var. utilis (L.), (c) Elephant grass: Pennisetum purpureum (Schum), (d) Guinea grass: Panicum maximum (Jacq)\} and a control (no mulch application). The five treatments were arranged in a randomized complete block design with four replications. The size of the land used for the experiment was $255 \mathrm{~m}^{2}$. Each block comprised 5 plots, each of which measured $3 \times 3 \mathrm{~m}^{2}$. Blocks were $1 \mathrm{~m}$ apart, and the plots were $0.5 \mathrm{~m}$ apart. The same site was used in the two years of the study.

\subsection{Planting of okra and application of mulch}

After land preparation (ploughing and harrowing), the site was then laid out to the require plot size of $3 \mathrm{~m} \times 3 \mathrm{~m}$. Planting of okra variety NHAe-47-4 was done early October for 2015 cropping season and early March for 2016 cropping season. Three seeds of okra were sown per hole at inter-row spacing of $0.6 \mathrm{~m}$ and $0.6 \mathrm{~m}$ intra-row spacing manually using simple hand held grain driller giving a plant population of 27,778 plants ha ${ }^{-1}$. At two weeks after sowing, thinning to one plant per stand was done and this was followed by manual weeding using hand hoe before treatment application. Subsequent weeding was done as needed. Fresh Tropical kudzu (Pueraria phaseoloides), Velvetbean (Mucuna pruriens), Elephant grass (Pennisetum purpureum) and Guinea grass (Panicum maximum) were collected from a nearby farm and hedge containing green tender stems and the leaves. The mulches were applied directly to the plots after the mulch materials were harvested at the rate of $5 \mathrm{tha}^{-1}$ to cover the soil. Insect pests were controlled by spraying cypermethrin weekly at the rate of $30 \mathrm{ml}$ per $10 \mathrm{~L}$ of water from 2 weeks after sowing till 4 weeks after sowing.

\subsection{Determination of soil physical and chemical properties}

Two weeks after mulch application, determination of bulk density, total porosity and gravimetric water content and soil temperature in all plots commenced and was repeated at 4, 6, 8, 10 and 12 weeks after mulch application. Five undisturbed samples
(0.04 m diameter, $0.10 \mathrm{~m}$ high) were collected at $0-0.10 \mathrm{~m}$ depth from the centre of each plot at random and $0.15 \mathrm{~m}$ away from each okra plant using core steel sampler. The samples were used to evaluate bulk density, total porosity and gravimetric water content after oven-drying at $100^{\circ} \mathrm{C}$ for $24 \mathrm{~h}$. Total porosity was calculated from the value of bulk density and particle density of $2.65 \mathrm{Mg} \mathrm{m}^{-3}$. Soil temperature was determined at 15:00 h with a soil thermometer inserted to $0.10 \mathrm{~m}$ depth. Six readings were made per plot at each sampling time and mean values were computed.

Before the start of the experiment, soil physical properties (bulk density and total porosity) were determined as described above. Soil samples were collected at a depth of $0-0.15 \mathrm{~m}$ randomly from different points to represent the experimental area and bulked together to make a composite soil for determination of particlesize and chemical analysis. Particle-size analysis was done using the hydrometer method (Gee and Or, 2002). At the end of the experiment each year, soil samples were also collected from each experimental plot for chemical analysis. The soil samples collected were air dried, ground, and sieved through a $2 \mathrm{~mm}$ sieve. The sieved soil samples were taken to the laboratory for chemical analysis as described by Carter (1993). Soil organic carbon was determined by the procedure of Walkley and Black using the dichromate wet oxidation method. The total $\mathrm{N}$ was determined by micro-Kjeldahl digestion and distillation techniques, available $\mathrm{P}$ was extracted using Bray-1 solution and determined by molybdenum blue colorimetry. Exchangeable $\mathrm{K}, \mathrm{Ca}$ and $\mathrm{Mg}$ were extracted using $1 \mathrm{~N}$ ammonium acetate. Thereafter, $\mathrm{K}$ was determined using a flame photometer and $\mathrm{Ca}$ and $\mathrm{Mg}$ by the EDTA titration method. Soil $\mathrm{pH}$ was determined by using a soil-water medium at a ratio of $1: 2$ using digital electronic $\mathrm{pH}$ meter.

\subsection{Analysis of okra leaves and mulch materials}

At mid-flowering of okra plant in each year, leaf samples were collected randomly from each plot, oven-dried for $24 \mathrm{~h}$ at $80^{\circ} \mathrm{C}$ and ground in a Willey mill. These samples were analysed for leaf $\mathrm{N}$, P, K, Ca and Mg as described by Tel and Hagarty (1984). Leaf N was determined by the micro-Kjeldahl digestion method. Ground 
Table 5

Effect of various mulch materials on soil chemical properties in 2015 (dry) season and 2016 (wet) season okra production.

\begin{tabular}{|c|c|c|c|c|c|c|c|c|}
\hline Year/season & Mulch material & $\mathrm{pH}$ (water) & $\mathrm{OM}(\%)$ & $\mathrm{N}(\%)$ & $\mathrm{P}\left(\mathrm{mg} \mathrm{kg}^{-1}\right)$ & $\mathrm{K}\left(\mathrm{cmol} \mathrm{kg}^{-1}\right)$ & $\mathrm{Ca}\left(\mathrm{cmol} \mathrm{kg}^{-1}\right)$ & $\mathrm{Mg}\left(\mathrm{cmol} \mathrm{kg}^{-1}\right)$ \\
\hline \multirow[t]{5}{*}{2015 (Dry) } & Control & $5.50 \mathrm{~b}$ & $1.02 \mathrm{c}$ & $0.02 \mathrm{e}$ & $4.3 e$ & $0.51 \mathrm{e}$ & $1.01 \mathrm{e}$ & $0.43 e$ \\
\hline & Pueraria phaseoloides & $6.42 \mathrm{a}$ & $2.15 a$ & $0.23 a$ & $34.5 b$ & $2.03 a$ & $4.81 \mathrm{~b}$ & $0.94 a$ \\
\hline & Mucuna pruriens & $6.21 \mathrm{a}$ & $2.21 \mathrm{a}$ & $0.20 \mathrm{~b}$ & $39.9 a$ & $1.02 \mathrm{~b}$ & $6.21 \mathrm{a}$ & $0.66 \mathrm{~b}$ \\
\hline & Pennisetum purpureum & $6.32 a$ & $1.59 \mathrm{~b}$ & $0.19 c$ & $11.9 d$ & $0.86 c$ & $3.11 \mathrm{~d}$ & $0.53 c$ \\
\hline & Paniucum maximum & $6.57 a$ & $1.51 \mathrm{~b}$ & $0.16 \mathrm{~d}$ & $28.8 \mathrm{c}$ & $0.72 d$ & $3.71 \mathrm{c}$ & $0.49 d$ \\
\hline \multirow[t]{5}{*}{2016 (Wet) } & Control & $5.60 \mathrm{~b}$ & $1.50 \mathrm{c}$ & $0.10 \mathrm{e}$ & $5.6 \mathrm{e}$ & $0.15 c$ & $1.12 \mathrm{c}$ & $0.29 \mathrm{e}$ \\
\hline & Pueraria phaseoloides & $6.48 \mathrm{a}$ & $3.65 a$ & $0.27 a b$ & $40.3 a$ & $0.23 a$ & $2.66 a$ & $0.96 a$ \\
\hline & Mucuna pruriens & $6.32 \mathrm{a}$ & $3.73 a$ & $0.29 a$ & $36.5 b$ & $0.24 \mathrm{a}$ & $2.78 \mathrm{a}$ & $0.83 b$ \\
\hline & Pennisetum purpureum & $6.43 a$ & $2.10 \mathrm{~b}$ & $0.19 \mathrm{~cd}$ & $12.6 \mathrm{~d}$ & $0.19 b$ & $1.59 \mathrm{~b}$ & $0.58 \mathrm{c}$ \\
\hline & Paniucum maximum & $6.59 a$ & $2.15 b$ & $0.18 \mathrm{~d}$ & $29.6 c$ & $0.19 b$ & $1.60 \mathrm{~b}$ & $0.50 \mathrm{~d}$ \\
\hline Year $(Y)$ & & ns & $*$ & $*$ & $*$ & $*$ & * & * \\
\hline Mulch (M) & & ns & $*$ & $*$ & $*$ & $*$ & $*$ & * \\
\hline $\mathrm{Y} \times \mathrm{M}$ & & ns & $*$ & * & $*$ & $*$ & * & * \\
\hline
\end{tabular}

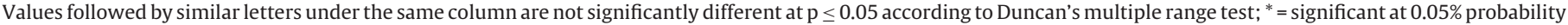
level; ns = not significant.

Table 6

Effect of various mulch materials on leaf nutrient concentrations of okra in 2015 (dry) and 2016 (wet) seasons.

\begin{tabular}{|c|c|c|c|c|c|c|}
\hline Year/season & Mulch material & $\mathrm{N}(\%)$ & $\mathrm{P}(\%)$ & $\mathrm{K}(\%)$ & $\mathrm{Ca}(\%)$ & $\operatorname{Mg}(\%)$ \\
\hline \multirow[t]{5}{*}{2015 (Dry) } & Control & $0.10 \mathrm{c}$ & $0.14 \mathrm{e}$ & $0.46 c$ & $0.34 d$ & $0.08 \mathrm{e}$ \\
\hline & Pueraria phaseoloides & $0.64 b$ & $0.17 \mathrm{bc}$ & $0.69 b$ & $0.60 \mathrm{~b}$ & $0.11 \mathrm{~cd}$ \\
\hline & Mucuna pruriens & $0.66 b$ & $0.16 \mathrm{~cd}$ & $0.66 \mathrm{~b}$ & $0.56 b c$ & $0.10 \mathrm{~d}$ \\
\hline & Pennisetum purpureum & $0.96 a$ & $0.19 a$ & $0.87 \mathrm{a}$ & $0.73 a$ & $0.22 \mathrm{ab}$ \\
\hline & Paniucum maximum & $0.94 a$ & $0.18 \mathrm{ab}$ & $0.82 \mathrm{a}$ & $0.76 a$ & $0.24 \mathrm{a}$ \\
\hline \multirow[t]{5}{*}{2016 (Wet) } & Control & $0.73 c$ & $0.16 \mathrm{~d}$ & $0.58 \mathrm{c}$ & $0.36 \mathrm{c}$ & $0.09 \mathrm{~d}$ \\
\hline & Pueraria phaseoloides & $1.58 \mathrm{a}$ & $0.29 \mathrm{a}$ & $2.10 \mathrm{a}$ & $1.26 a$ & $0.12 \mathrm{ab}$ \\
\hline & Mucuna pruriens & $1.62 \mathrm{a}$ & $0.28 \mathrm{a}$ & $2.17 a$ & $1.28 \mathrm{a}$ & $0.13 a$ \\
\hline & Pennisetum purpureum & $1.10 \mathrm{~b}$ & $0.19 b$ & $1.20 \mathrm{~b}$ & $0.95 b$ & $0.10 c$ \\
\hline & Paniucum maximum & $1.13 b$ & $0.18 b c$ & $1.25 b$ & $0.97 \mathrm{~b}$ & $0.10 c$ \\
\hline Year $(\mathrm{Y})$ & & $*$ & * & $*$ & * & $*$ \\
\hline Mulch (M) & & $*$ & * & * & $*$ & * \\
\hline $\mathrm{Y} \times \mathrm{M}$ & & $*$ & * & $*$ & $*$ & $*$ \\
\hline
\end{tabular}

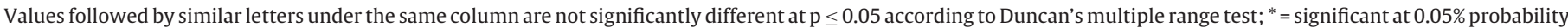
level.

samples were digested with nitric-perchloric-sulphuric acid mixture for the determination of $\mathrm{P}, \mathrm{K}, \mathrm{Ca}$ and $\mathrm{Mg}$. Phosphorus was determined colorimetrically using the vanadomolybdate method, $\mathrm{K}$ was determined using a flame photometer and $\mathrm{Ca}$ and $\mathrm{Mg}$ were determined by the EDTA titration method (Horwitz and Latimer, 2005).

Just prior to application to the plots, the samples of the mulch materials used were similarly analysed as described above for okra leaves. The percentage of organic carbon in the mulch materials was determined by the Walkley and Black procedure using the dichromate wet oxidation method.

\subsection{Determination of growth and yield parameters}

Collection of data started three weeks after mulch application, and consecutively at one week interval after the first collection. Growth parameters measured were plant height (by the use of meter rule), number of leaves (by counting), and stem diameter (by using of vernier caliper). Edible pods were harvested at four day intervals and weighed. Pod weight was evaluated based on the cumulative harvests per plot. For dry season okra, fruits were harvested until January 2016 while for wet season okra, fruits were harvested until June 2016.

\subsection{Data analysis}

Data collected were subjected to analysis of variance (ANOVA) using the SPSS 21 statistical package. Treatment means were separated using the Duncan's multiple range test at 5\% probability level.
Economics of okra production under the different mulch materials were also determined.

\section{Results}

\subsection{The meteorological data of the study area}

The results of the meteorological data of the study area are presented in Table 1 . The total rainfall for the months of October, November, December 2015 and January 2016 (dry season) was $201.4 \mathrm{~mm}$ while that of March, April, May and June 2016 (wet season) was $618.3 \mathrm{~mm}$. The corresponding mean air temperature for the period for dry season was $27.0^{\circ} \mathrm{C}$ and $24.2^{\circ} \mathrm{C}$ for wet season. Wet season had $207.0 \%$ higher rainfall compared with dry season, while dry season had $11.6 \%$ higher air temperature compared with wet season.

3.2. Soil physical and chemical properties of the experimental site before the start of the experiment and chemical composition of mulch materials used for the experiment

The soil physical and chemical properties of the experimental site before the start of the experiment in 2015 are shown in Table 2. The soil was sandy loam in texture, high in bulk density, acidic and low in organic matter (OM), total $\mathrm{N}$, exchangeable $\mathrm{K}, \mathrm{Ca}$ and $\mathrm{Mg}$ and only adequate in available Paccording to the critical levels of $3 \% \mathrm{OM}$, $0.2 \% \mathrm{~N}, 10.0 \mathrm{mg} \mathrm{kg}^{-1}$ available $\mathrm{P}, 0.16-0.20 \mathrm{cmol} \mathrm{kg}^{-1}$ exchangeable $\mathrm{K}, 2.0 \mathrm{cmol} \mathrm{kg}^{-1}$ exchangeable Ca and $0.40 \mathrm{cmol} \mathrm{kg}^{-1}$ exchangeable 
Table 7

Effect of various mulch materials on yield and growth indices of okra in 2015 (dry) and 2016 (wet) seasons.

\begin{tabular}{|c|c|c|c|c|c|}
\hline Year/season & Mulch material & Pod yield ( $\left.\mathrm{tha}^{-1}\right)$ & Number of leaves plant ${ }^{-1}$ & Stem diameter $(\mathrm{m})$ & Plant height (m) \\
\hline \multirow[t]{5}{*}{2015 (Dry) } & Control & $2.6 \mathrm{c}$ & $15 \mathrm{e}$ & $0.05 c$ & $0.34 \mathrm{~d}$ \\
\hline & Pueraria phaseoloides & $4.5 b$ & $20 \mathrm{~cd}$ & $0.07 b$ & $0.64 c$ \\
\hline & Mucuna pruriens & $4.4 \mathrm{~b}$ & $21 \mathrm{bc}$ & $0.07 b$ & $0.62 c$ \\
\hline & Pennisetum purpureum & $6.6 a$ & $23 a$ & $0.08 \mathrm{a}$ & $0.71 \mathrm{ab}$ \\
\hline & Paniucum maximum & $6.7 a$ & $22 \mathrm{ab}$ & $0.08 a$ & $0.74 a$ \\
\hline \multirow[t]{5}{*}{2016 (Wet) } & Control & $3.6 \mathrm{c}$ & $16 c$ & $0.05 c$ & $0.38 c$ \\
\hline & Pueraria phaseoloides & 7.9a & $26 a$ & $0.08 \mathrm{a}$ & $0.78 \mathrm{a}$ \\
\hline & Mucuna pruriens & $8.1 \mathrm{a}$ & $26 a$ & $0.08 \mathrm{a}$ & $0.79 a$ \\
\hline & Pennisetum purpureum & $5.2 \mathrm{~b}$ & 24ab & $0.06 \mathrm{~b}$ & $0.65 b$ \\
\hline & Paniucum maximum & $5.0 \mathrm{~b}$ & $24 \mathrm{ab}$ & $0.06 \mathrm{~b}$ & $0.66 b$ \\
\hline Year $(Y)$ & & $*$ & ns & * & * \\
\hline Mulch (M) & & $*$ & ns & $*$ & $*$ \\
\hline $\mathrm{Y} \times \mathrm{M}$ & & $*$ & ns & $*$ & $*$ \\
\hline
\end{tabular}

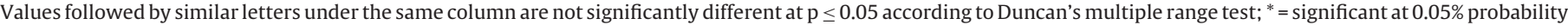
level; ns = not significant

Table 8

Correlation coefficient between mean values of soil physical properties and pod yield and plant height of okra in 2015 (dry) and 2016 (wet) seasons.

\begin{tabular}{|c|c|c|c|c|c|c|c|c|}
\hline & \multicolumn{2}{|c|}{ Bulk density } & \multicolumn{2}{|c|}{ Total porosity } & \multicolumn{2}{|c|}{ Moisture content } & \multicolumn{2}{|c|}{ Temperature } \\
\hline & 2015(dry) & 2016(wet) & 2015(dry) & 2016(wet) & 2015(dry) & 2016(wet) & 2015(dry) & 2016(wet) \\
\hline Pod yield & $-0.969 * *$ & $-455 \mathrm{~ns}$ & $0.968^{* *}$ & $0.453 \mathrm{~ns}$ & $0.993^{* *}$ & $0.475 \mathrm{~ns}$ & $-0.992^{* *}$ & $-0.542 \mathrm{~ns}$ \\
\hline Plant height & $0.993^{* *}$ & $-783 n s$ & $0.974^{* *}$ & $0.782 \mathrm{~ns}$ & $0.893^{*}$ & $0.799 \mathrm{~ns}$ & $0.947^{* *}$ & $0.841 \mathrm{~ns}$ \\
\hline
\end{tabular}

${ }^{* *}=$ Correlation is significant at the 0.01 level; ${ }^{*}=$ correlation is significant at the 0.05 level; ns $=$ not significant.

Mg recommended for crop production in ecological zones of Nigeria (Akinrinde and Obigbesan, 2000).

The chemical analysis of green leaves of Pueraria, Mucuna, Pennisetum and Panicum used for the experiment showed that legume mulch materials (Pueraria and Mucuna) have lower C:N ratio compared with grass mulch materials (Pennisetum and Panicum) (Table 3). Mucuna has the lowest $\mathrm{C}: \mathrm{N}$ ratio and there were no significant differences $(\mathrm{p} \leq 0.05)$ between Pennisetum and Panicum in terms of their $\mathrm{C}: \mathrm{N}$ ratio. Except for $\mathrm{Ca}$ and $\mathrm{Mg}$, legume mulch materials have better chemical composition compared with grass mulch materials.

\subsection{Effect of various mulch materials on soil physical properties}

Data on the effect of various mulch materials on soil physical properties in 2015 (dry) season and 2016 (wet) season okra production are presented in Table 4. In both years, application of mulch significantly $(\mathrm{p} \leq 0.05)$ reduced bulk density and soil temperature and increased porosity and moisture content compared with the control. In 2015, Pueraria and Mucuna plots had higher bulk density and lower porosity compared with Pennisetum and Panicum. Moisture content was also lower and soil temperature higher in Pueraria and Mucuna plots compared with Pennisetum and Panicum plots. In all cases there were no significant differences in the soil physical properties between Pennisetum and Panicum and between Pueraria and Mucuna. In 2016, there were no significant differences between values of soil bulk density, porosity, moisture content and temperature between the various mulch materials.

Year (Y) and Mulch materials (M) when considered as an individual factor influenced bulk density, porosity, moisture content and temperature significantly. The interaction between Year and Mulch materials ( $\mathrm{Y} \times \mathrm{M}$ ) was also significant for bulk density, porosity, moisture content and temperature.

\subsection{Effect of various mulch materials on soil chemical properties}

Data presented in Table 5 are the results of the soil chemical properties in 2015 and 2016. In both years, Pueraria, Mucuna, Pen- nisetum and Panicum increased soil $\mathrm{pH}, \mathrm{OM}, \mathrm{N}, \mathrm{P}, \mathrm{K}, \mathrm{Ca}$ and $\mathrm{Mg}$ compared with the control. There were no significant differences in the $\mathrm{pH}$ values of the various mulch materials in both years. Also in both years, legume mulch materials (Pueraria and Mucuna) produced higher values of $\mathrm{OM}, \mathrm{N}, \mathrm{P}, \mathrm{K}, \mathrm{Ca}$ and $\mathrm{Mg}$ compared with grass mulch materials (Pennisetum and Panicum). Year ( $\mathrm{Y}$ ) and Mulch materials (M) when considered as an individual factor influenced soil chemical properties except soil $\mathrm{pH}$. The interaction between $\mathrm{Y}$ $\mathrm{x}$ M was significant for $\mathrm{OM}, \mathrm{N}, \mathrm{P}, \mathrm{K}, \mathrm{Ca}$ and $\mathrm{Mg}$. The interaction $\mathrm{Y} \mathrm{x}$ $\mathrm{M}$ for soil $\mathrm{pH}$ was not significant.

\subsection{Effect of various mulch materials on leaf nutrient concentrations of okra}

The effect of various mulch materials on leaf nutrient concentrations of okra in 2015 and 2016 are shown in Table 6. In both years, application of mulch increased the leaf concentrations of okra compared with the control. In 2015, grass mulch materials (Pennisetum and Panicum) had higher values of leaf N, P, K, Ca and Mg compared with legume mulch materials (Pueraria and Mucuna). However, in 2016, legume mulch materials gave higher leaf nutrient concentrations of okra compared with grass mulch materials. In both years, there were no significant differences between Pennisetum and Panicum, and between Pueraria and Mucuna for leaf N, P, K, Ca and $\mathrm{Mg}$. The individual factors $\mathrm{Y}$ and $\mathrm{M}$ and interaction $\mathrm{Y} \times \mathrm{M}$ were significant for $\mathrm{N}, \mathrm{P}, \mathrm{K}, \mathrm{Ca}$ and $\mathrm{Mg}$.

\subsection{Effect of various mulch materials on yield and growth indices of okra}

The data on the effect of various mulch materials on the yield and growth indices of okra plant in 2015 and 2016 are presented in Table 7. In both years, application of mulch increased the yield and growth indices of okra plant significantly $(\mathrm{p} \leq 0.05)$ compared with the control. In 2015, grass mulch materials (Pennisetum and Panicum) significantly ( $\mathrm{p} \leq 0.05$ ) produced higher values of okra pod yield, number of leaves, stem girth and plant height compared with legume mulch materials (Pueraria and Mucuna). Using the mean of 


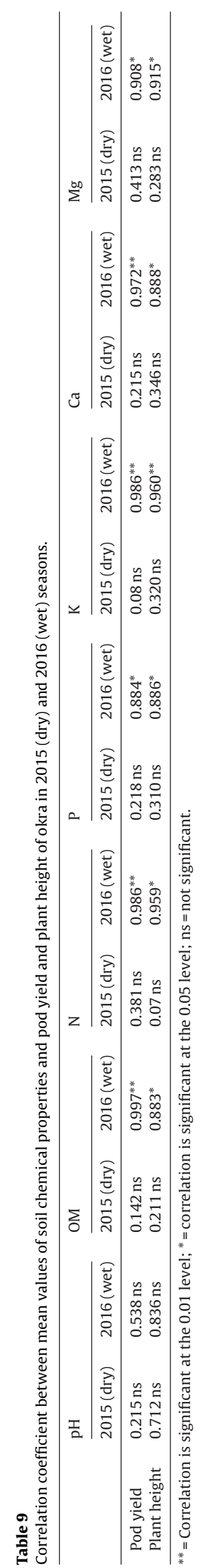

the two mulch materials in 2015 , grass mulch materials produced higher pod yield by $49 \%\left(2.2 \mathrm{tha}^{-1}\right)$ and $158 \%\left(4.1 \mathrm{tha}^{-1}\right)$ compared with legume mulch materials and the control, respectively. In 2016, legume mulch materials produced significantly higher fruit yield, stem girth and plant height of okra compared with grass mulch materials. The values of number of leaves per plant between the various mulch materials are not significant. Also, using the means of the two mulch materials, legume mulch materials increased the pod yield of okra in 2016 by $56 \%$ (2.9 $\left.\mathrm{tha}^{-1}\right)$ and $122 \%\left(4.4 \mathrm{tha}^{-1}\right)$ compared with grass materials and the control, respectively. When studied as individual factors, Year (Y) and Mulch (M) were significant for fruit yield, stem diameter and plant height of okra, but was not significant for number of leaves per plant. The interactive effect $\mathrm{Yx}$ M was also significant for pod yield, stem girth and plant height of okra, but not significant for number of leaves per plant.

The correlation coefficient between soil physical properties and pod yield and plant height of okra in 2015 and 2016 (Table 8) showed that in 2015, yield and plant height of okra were significant for bulk density, porosity, soil moisture content and temperature, but in 2016 the values were not significant. Also, the correlation coefficient between soil chemical properties and pod yield and plant height of okra (Table 9) showed that except for soil pH which do not give significant different in both years, OM, N, P, K, Ca, and Mg were significant in 2016, but not significant in 2015.

\subsection{Economics of okra production under different mulch materials at different cropping seasons}

Table 10 shows the data on the economics of okra production under different mulch materials at different cropping seasons. The cost of cutting and transportation of Pueraria and Mucuna was higher and similar ( $\mathbf{3 0 , 0 0 0 )}$ in both seasons (years) compared with that of Pennisetum and Panicum which were also similar ( $\mathbf{N 2 5 , 0 0 0 )}$ in both years. The economic returns were highest with Panicum ( $\mathbb{1} 1,615,000 \mathrm{ha}^{-1}$ ) and Pennisetum ( $\mathrm{N1}, 575,000 \mathrm{ha}^{-1}$ ) mulches when compared with legume mulches in 2015. Whereas in 2016, Mucuna ( $\mathrm{N} 285,000 \mathrm{ha}^{-1}$ ) followed by Pueraria ( $\mathrm{N} 271,000 \mathrm{ha}^{-1}$ ) mulches gave the highest economic returns compared with grass mulches. Economically, Pennisetum and Panicum applied during lean season of okra production proved to be more cost effective and profitable than legume mulches (Pueraria and Mucuna) either applied at lean or peak season as shown by their high return rates or value cost ratio of 63:1 and 65:1, respectively for Pennisetum and Panicum. Based on the objective function of profit maximization, the optimum returns were recorded by Panicum maximum under lean season in 2015 with a net return of $\mathrm{A} 1,615,000 \mathrm{ha}^{-1}$ and a benefit cost ratio of 65:1 and Mucuna pruriens under peak season in 2016 with a net return of $285,000 \mathrm{ha}^{-1}$ and a benefit cost ratio of 10:1. This shows that farmers stand in better position to make more profit from okra production through the use of these mulch materials at the appropriate season. According to Table 10, the use of mulch had a much greater economic benefit during the dry season than during the wet season.

\section{Discussion}

Results showed that application of mulch reduced bulk density and soil temperature and increased porosity and moisture content compared with the control. The reduction in soil bulk density observed in mulch plots compared to the control could be attributed to increase in soil organic matter (SOM) from the degraded organic residues by microorganisms. The presence of vegetative surface mulches should have increased activities of beneficial soil fauna in organic matter decomposition which led to enhancement of soil porosity and reduction in bulk density. Lower 
Table 10

Economics of producing okra under different mulch materials in 2015 (dry) and 2016 (wet) seasons.

\begin{tabular}{|c|c|c|c|c|c|c|c|}
\hline Year/season & $\begin{array}{l}\text { Mulch } \\
\text { material }\end{array}$ & $\begin{array}{l}\text { Monetary } \\
\text { gain } \\
\left(\mathrm{A} \mathrm{ha}^{-1}\right)\end{array}$ & $\begin{array}{l}\text { Production } \\
\text { increase value }\end{array}$ & $\begin{array}{l}\text { Production } \\
\text { Increase } \\
(\%)\end{array}$ & $\begin{array}{l}\text { Cost of cutting } \\
\text { and transporting } \\
\text { of mulches } \\
\left(\mathrm{Nha}^{-1}\right)\end{array}$ & $\begin{array}{l}\text { Net return over } \\
\text { each mulch } \\
\text { material }\end{array}$ & $\begin{array}{l}\text { Return rate or } \\
\text { benefit/ cost ratic } \\
\text { of each mulch }\end{array}$ \\
\hline \multirow[t]{5}{*}{2015 (Dry) } & Control & $1,040,000$ & - & - & - & - & - \\
\hline & Pueraria & $1,800,000$ & 760,000 & 73 & 30,000 & 730,000 & 24 \\
\hline & Mucuna & $1,760,000$ & 720,000 & 69 & 30,000 & 690,000 & 23 \\
\hline & Pennisetum & $2,640,000$ & $1,600,000$ & 154 & 25,000 & $1,575,000$ & 63 \\
\hline & Paniucum & $2,680,000$ & $1,640,000$ & 158 & 25,000 & $1,615,000$ & 65 \\
\hline \multirow[t]{5}{*}{2016 (wet) } & Control & 252,000 & - & - & - & - & - \\
\hline & Pueraria & 553,000 & 301,000 & 119 & 30,000 & 271,000 & 9 \\
\hline & Mucuna & 567,000 & 315,000 & 125 & 30,000 & 285,000 & 10 \\
\hline & Pennisetum & 364,000 & 112,000 & 44 & 25,000 & 87,000 & 3 \\
\hline & Paniucum & 350,000 & 98,000 & 39 & 25,000 & 73,000 & 3 \\
\hline
\end{tabular}

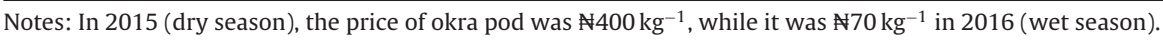

$\mathrm{N} 320.00$ is equivalent to 1.00 US\$ in 2015; $\mathrm{N} 410.00$ is equivalent to 1.00 US\$ in 2016 .

soil temperature and increased moisture content was observed under mulch plots compared with unmulched plots. The results agreed with the findings of Adeoye (1984); Agele et al. (2000) and Agele et al. (2010). Adeoye (1984) found that application of mulch at $5 \mathrm{tha}^{-1}$ reduced maximum temperature at $5 \mathrm{~cm}$ by $7^{\circ} \mathrm{C}$ and at $10 \mathrm{~cm}$ by $4{ }^{\circ} \mathrm{C}$ and that mulched soils contained higher moisture to depth of $6 \mathrm{~cm}$ compared with unmulched soils. Similarly, Agele et al. (2010), conducted experiment to the suitability of some mulch materials for soil improvement and yield of sunflower (Helianthus annuus L.), compared with unmulched plots and found that mulching significantly improved soil moisture and temperature regimes. Other studies from agricultural fields from the humid tropics had shown that mulching ameliorates soil moisture deficit and temperature regime, improves water infiltration, reduces evaporation and run-off and improves soil structure (Olasantan, 1988). The better soil physical properties of grass mulch materials in 2015 (dry season) compared with legume mulch materials could be related to grass mulch materials slower break down, thus providing better soil moisture conservation and reducing soil temperature. Grass mulch provides better insulation material and thus protected the soil from direct sunlight and prevented it from hard setting and toughness by controlling rates of evaporation. Because of higher soil moisture content and lower soil temperature compared with the control and legume mulch materials (Table 4). Guinea grass (Panicum maximum) was found to significantly reduced soil temperature within the top $20 \mathrm{~cm}$ of soil (Cadavid et al., 1998) whereas soil temperature was also found to reduce below supra optimum level by application of $2 \mathrm{tha}^{-1}$ grass mulch (Mbagwu, 1991).

In both years, mulch materials increased soil $\mathrm{pH}, \mathrm{OM}, \mathrm{N}, \mathrm{P}, \mathrm{K}$, $\mathrm{Ca}$ and $\mathrm{Mg}$ compared with the control. The soil fertility enhancement by mulch obtained in this study could be attributed to the promotion of microbial activity and consequent decomposition of organic materials to organic matter and release of nutrient elements such as N, P, K Ca and Mg. Other authors (Yusuf and Fawole, 2006; Agyenim Boateng, 1997; Ewulo et al., 2011) also found that Pennisetum, Panicum, Pueraria and Mucuna mulches decomposed to release nutrients to the soil. N levels were slightly increased from $0.99 \%$ to values over $1 \%$ at Ejura in the forest savanna transition zone of Ghana when mucuna was incorporated or used as mulch (Agyenim Boateng, 1997). Ewulo et al. (2011) also found that in south west Nigeria, weed residues are effective sources of N, P, K, $\mathrm{Ca}$ and $\mathrm{Mg}$ for yam plants. The higher values of $\mathrm{OM}, \mathrm{N}, \mathrm{P}, \mathrm{K}, \mathrm{Ca}$ and $\mathrm{Mg}$ released into the soil by legume mulches compared with grass mulches could be attributed to differences in the chemical compositions of the various mulch materials (Table 3 ). The quality of applied mulch materials had profound effects on soil chemical properties, which were related to the contents of organic $\mathrm{C}$ and $\mathrm{N}$ in the materials applied (Agele et al., 2010). Although grass mulches had moderate $\mathrm{C}: \mathrm{N}$ ratio 23:1 as against 30:1 minimum threshold ratio for net mineralization (Broadbent, 1986), yet legume mulch materials had lower values. The narrower the $\mathrm{C}$ : $\mathrm{N}$ ratio the faster the decomposition rate and hence the nutrients release into the soil (Alexander, 1977). The efficiency of nutrient recycling from applied crop/plant residues (mulches) is predicted on activity of soil microbial population which results from the decomposition of the applied materials (Agele et al., 2010). The significant differences in soil chemical properties between 2015 (dry) and 2016 (wet) seasons could be adduced to the fact that soil biological activities which causes degradation of mulch materials is severely limited during the dry period (2015), but with the onset of the rains [2016], there is a flush in microbial activity.

In both years, application of mulch increased leaf N, P, K, Ca and $\mathrm{Mg}$ concentrations of okra compared with the control. This was attributable to increase of nutrients in the soil by application of mulch leading to increased uptake by okra plants.

The increase in pod yield and growth indices of okra as a result of application of mulch in 2015 and 2016 compared with the control could be attributed to better soil conditions resulting from lower soil bulk density and temperature and increased porosity, moisture content and soil chemical properties in the mulched plots compared with the unmulched plots. The higher values of pod yield and growth indices of okra in grass mulch (Pennisetum and Panicum) plots in 2015 compared with legume mulch (Pueraria and Mucuna) plots could be adduced to their lower bulk density and soil temperature and higher porosity and soil moisture content. This observation is also consistent with the fact that significant correlations were recorded between soil physical properties and okra yield in 2015 and the correlation between soil chemical properties and okra pod yield and plant height were not significant. This shows that the yield and growth of okra in the lean (dry) season is more dependent on soil physical properties and not the chemical properties. In fact, the legume mulch materials with high chemical properties had lower yield compared with grass mulch materials. The lower bulk density of the Pennisetum and Panicum mulches would have enhanced root growth and therefore nutrient uptake. The improved soil moisture and soil temperature regimes also enhanced root development and nutrient uptake which favoured shoot biomass development in Pennisetum and Panicum plots. The higher pod yield and growth indices of okra in 2016 was due to increase in soil chemical properties as a result of decomposition of the legume mulch materials (Pueraria and Mucuna) due to their lower C: $\mathrm{N}$ ratio compared with grass mulch materials (Pennisetum and Panicum) with higher C:N ratio. Table 9 revealed that pod yield and plant height of okra was 
dependent on soil chemical properties. Therefore, the soil fertility enhancement by legume mulch obtained in 2016 (wet season) was due to promotion of microbial activity and consequent decomposition of organic materials. Soil microorganisms play an important role in regulating soil fertility and transforming organic matter, and their activity relies on the availability of decomposable materials (Paul and Mannan, 2006; Purvis, 1990).

\section{Conclusions}

Application of mulch \{Tropical kudzu (Pueraria phaseoloides), Velvetbean (Mucuna pruriens) Elephant grass (Pennisetum purpureum) Guinea grass (Panicum maximum)\} reduced bulk density, soil temperature and increased porosity, soil moisture content, $\mathrm{pH}$, $\mathrm{OM}$, soil and leaf $\mathrm{N}, \mathrm{P}, \mathrm{K}, \mathrm{Ca}, \mathrm{Mg}$, pod yield and growth indices of okra compared with the control. The performance of okra in the dry season was dependent on soil physical properties whereas the performance during the wet season was dependent on soil chemical properties. Therefore the use of grass materials as mulch in the dry season and the use of legume mulches during the wet season maximized yields.

\section{References}

Abd El-Kader, A.A., Shaaban, S.M., Abd El-Fattah, M.S., 2010. Effect of irrigation levels and organic compost on okra plants (Abelmoschus esculentus L.) grown in sandy calcareous soil. Agric. Biol. J. North Am. 1 (3), 225-231.

Adekalu, K.O., Olorunfemi, I.A., Osunbitan, J.A., 2006. Grass mulching effect on infiltration, surface runoff and soil loss of three agricultural soils in Nigeria. Bioresour. Technol. 98 (4), 912-917.

Adekiya, A.O., Agbede, T.M., Aboyeji, C.M., 2015. Effect of time of siam weed (Chromolaena odorata) mulch application on soil properties, growth and tuber yield of white yam. N. Y. Sci. J. 8 (9), 58-64.

Adeoye, K.B., 1984. Influence of grass mulch on soil temperature, soil moisture and yield of maize and gero millet in a savanna zone soil. Samaru J. Agric. Res. 2, $87-97$

Agele, S.O., Iremiren, G.O., Ojeniyi, S.O., 2000. Effects of tillage and mulching on the growth, development and yield of late-season tomato (Lycopersicon esculentum L.) in the humid south of Nigeria. J. Agric Sci. 134 (1), 55-59.

Agele, S.O., Olaore, J.B., Akinbode, F.A., 2010. Effect of some mulch materials on soil physical properties, growth and yield of sunflower (Helianthus annuus L.). Adv. Environ. Biol. 4 (3), 368-375

Agyenim Boateng, S., 1997. Effects of Mucuna pruriens green manure on soil fertility and crop yield. In: Proceedings of the 14th and 15th Annual General Meetings of the Soil Science Society of Ghana, Accra, pp. 59-65.

Aina, P.O., 1979. Soil changes resulting from long-term management practices in western Nigeria. Soil Sci. Soc. Am. J. 43, 173-177.

Akinrinde, E.A., Obigbesan, G.O., 2000. Evaluation of the fertility status of selected soils for crop production in five ecological zones of Nigeria. In: Proceedings of the 26th Annual Conference of Soil Science Society of Nigeria, Ibadan, Nigeria, pp. 279-288.

Alexander, M., 1977. Introduction to Soil Microbiology, 2nd edn. John Wiley and Sons, New York, USA (467 pp).
Bamire, A.S., Oke, J.T.O., 2004. Profitability of vegetable farming under rainy and dry season production in southwestern Nigeria. J. Veg. Crop Prod. 9 (2), 11-18.

Batra, B.R., Malik, Y.S., Pandit, M.L., 1985. Evaluation of different mulching materials in okra production under dry farming condition. Agric. Sci. Digest. India 5, 8-9.

Broadbent, F.E., 1986. Effects of organic matter on nitrogen and phosphorus supply to plants. In: Chen, Avnimelech, Y. (Eds.), The Role of Organic Matter in Modern Agriculture. The Netherland Martinus Nijhoff Publishers, Dordrecht, pp. 13-27.

Cadavid, L.F., El-Sharkawy, M.A., Acosta, A., Sanchez, T., 1998. Long-term effects of mulch, fertilization and tillage on cassava grown in sandy soils in northern Colombia. Field Crops Res. 57 (1), 45-56.

Carter, M.R., 1993. Soil Sampling and Methods of Analysis. Canadian Society of Soil Science, Lewis publishers, Boca Raton, FL (823 pp).

Echo, 2003. Plant Information Sheet. N.F.T Meyers, USA http://echonet.org/.

Ewulo, B.S., Adeniyan, B.O., Ojeniyi, S.O., 2011. Effect of weed residues on growth, tuber yield and leaf nutrient content of yam in Southwest Nigeria. Int. J. Org. Agric. Res. Dev. 4, 1-11.

Farinde, A.J., Owolarafe, O.K., Ogungbemi, O.I., 2007. An overview of production, processing, marketing and utilization of okra in Egbedore Local Government Area of Osun State, Nigeria. Agric. Eng. Int. ix, 1-17 (Manuscript No. MES 07 002.).

Gee, G.W., Or, D., 2002. Particle-size analysis. In: Dane, J.H., Topp, G.C. (Eds.), Methods of Soil Analysis. Part 4. Physical Methods. Soil Science Society of America, Madison, Wisconsin, pp. 255-293 (No. 5).

Ghannad, M., Madani, H., Darvishi, H.H., 2014. Responses of okra crop to sowing time, irrigation interval and sowing methods in Shahrood region. Int. J. Agric. Crop Sci. 7 (10), 676-682.

Gupta, J.P., Gupta, G.N., 1987. Response of tomato and okra crops to irrigation and mulch in arid region of India. Agrochemica 31, 183-202.

Hochmuth, G.J., Hochmuth, R.C., Olson, S.M., 2015. Polyethylene Mulching for Early Vegetable Production in North Florida. University of Florida/Institute of Food and Agricultural Sciences (UF/IFAS), Florida A \& M University Cooperative Extension Program http://edis.ifas.ufl.edu.

Horwitz, W., Latimer, G.W. (Eds.), 2005, 16th edn. AOAC International, Gaithersburg, MD.

Mbagwu, J.S.C., 1991. Mulching an Ultisol in southern Nigeria: effects on physical properties and yield of maize and cowpea. J. Sci. Food Agric. 57, 517-526.

Olasantan, F.O., 1988. The effects on soil temperature and moisture content and crop growth and yield of intercropping maize with melon (Colocynthis vulgaris). Expl Agric. 24 (1), 67-74.

Ortiz-Ceballos, A.I., Fragoso, C., 2004. Earthworm populations under tropical maize cultivation: the effect of mulching with velvetbean. Biol. Fertil. Soils 39, 438-445.

Paul, G.C., Mannan, M.A., 2006. Integrated nutrient management in sugarcane to enhance sugar productivity. In: Proceedings, International Symposium on Technologies to Improve Sugar Productivity in Developing Countries, Gullin, Peoples Republic of China, pp. 108-121.

Purvis, C.E., 1990. Differential response of wheat to retained crop stubbles. 1. Effect of stubble type and degree of decomposition. Aust. J. Agric. Res. 41 (2), 225-242.

Tel, D.A., Hagarty, M. (Eds.), 1984. International Institute of Tropical Agriculture (IITA), University of Guelph, Ibadan, Nigeria, Guelph, Ontario, Canada (277 pp).

Tian, G., Hauser, S., Koutika, Lydie-Stella, Ishida, F., 2001. Pueraria cover crop fallow systems: benefits and applicability. In: Sustaining Soil Fertility in West Africa., pp. 137-155.

Wade, M.K., Sanchez, P.A., 1983. Mulching and green manure applications for continuous crop production in the Amazon Basin. Agron. J. 75 (1), 39-45.

Yusuf, S.A., Fawole, O.B., 2006. Effects of soil amendment with guinea grass (Panicum maximum Jacq) on the soil available phosphorous and yield of maize (Zea mays L.). J. Agric. Res. Dev. 5 (1), 75-84. 